\title{
PELATIHAN SMART RELAY / PROGRAMABLE LOGIC CONTROLLER (PLC) GURU LISTRIK DI SMK SWASTA HKBP KOTA P. SIANTAR PROV. SUMUT
}

\author{
Angelia Maharani Purba \\ Politeknik Negeri Medan, Medan, Indonesia \\ e-mail: angeliapurba@polmed.ac.id \\ Miduk Purba \\ Politeknik Negeri Medan, Medan, Indonesia \\ e-mail: midukpurba@polmed.ac.id \\ Eva Malina Simatupang \\ Politeknik Negeri Medan, Medan, Indonesia \\ e-mail: malinasimatupang@polmed.ac.id \\ Arlina Pratiwi Purba \\ Politeknik Negeri Medan, Medan, Indonesia \\ e-mail: arlinapurba@polmed.ac.id
}

\begin{abstract}
Abstrak
Sekolah Menengah Kejuruan (SMK) adalah pendidikan formal yang menyelenggarakan pendidikan kejuruan pada jenjang pendidikan menengah. Pendidikan kejuruan merupakan jenis pendidikan yang berorientasi pada keterampilan khusus sesuai dengan jurusannya. Seyogianya lulusan pendidikan kejuruan akan mudah memasuki pasar. Aktualisasi di lapangan tidak demikian. Dikutip dari News.okezone.com, lulusan SMK selama ini kurang memenuhi kualifikasi yang diharapkan akibat kurangnya kompetensi dan keterampilan lulusan sesuai dengan kompetensi di dunia usaha dunia industri (DUDI). Kebutuhan Sumber Daya Manusia (SDM) yang berkualitas di dunia industri menuntut SMK untuk membekali lulusannya sesuai dengan kompetensi-kompetensi yang dibutuhkan dunia usaha maupun dunia industri. Keberhasilan peserta didik dalam menguasai suatu kompetensi tidak lepas dari proses pendidikan. Salah satu bidang kompetensi yang berkembang begitu cepat saat ini adalah Teknologi Otomasi Industri, sehingga kompetensi semakin dibutuhkan dan menjadi tututan dewasa ini di lingkungan industri. Bidang kontrol otomasi industri banyak memberi kemudahan-kemudahan bagi masyarakat pengguna lebih khusus bagi seorang operator untuk mengoperasikan suatu sistim kontol. Dan Smart Relay/PLC yang dapat digunakan untuk mempermuda sistem pengontrolan yang dimaksud. Namun dalam pemanfaatannya smart relay/PLC harus diprogram secara khusus untuk menjalankannya. Dalam kurikulum SMK khususnya jurusan listrik, smart relay/PLC adalah pelajaran yang wajib diajarkan kepada siswa untuk meningkatkan kompetensi siswa, namun dengan terbatasnya peralatan modul dan guru yang mengajar bahkan ada sekolah yang sama sekali tidak mengajarkan khusus Smart Relay/PLC ini. Dalam lomba-lomba Ketrampilan Siswa (LKS) tingkat Nasional untuk SMK dengan jenis lomba bidang Electrical Instalasion beberapa tahun terakhir ini menjadi standar Nasional, Smart Relay/PLC sebagai pengontrol untuk suatu rangkaian instalasi yang dilengkapi dengan sensor-sensor, saklar-saklar, motor listrik dan peralatan lainnya. Smart Relay/PLC sudah menjadi standar lomba LKS tingkat Nasional. Untuk itu dengan
\end{abstract}


melihat kondisi serta kebutuhan sekolah untuk menunjang pelajaran tentang smart relay/PLC maka sebagai institusi pendidikan vokasi terpanggil untuk membantu melengkapi peralatan dan pelatihan dasar Smart Relay/Programmable Logic Controller (PLC) dengan metode pembelajaran Trainer Human Machine Interface (Trainer HMI) untuk meningkatkan kompetensi guru/pengajar dibidang kontrol industri.

Keywords - smart relay, PLC, rangkaian kontrol instalasi

\section{PENDAHULUAN}

ulusan SMK adalah tenaga kerja yang paling banyak diserap oleh industri, hal

-ini dikarenakan lulusan SMK memiliki kemampuan dan keterampilan khusus yang kompeten dalam bidangnya masing-masing. Namun demikian, masih banyak lulusan SMK yang belum mampu mengoptimalkan kemampuannya di dunia industi contohnya dalam bidang otomasi industri yaitu Smart Relay/PLC (Programmable Logic Controller). Hampir semua industri nasional maupun internasional menggunakan PLC dalam pabrik-pabriknya. Smart Relay/PLC merupakan salah satu mata pelajaran yang diajarkan bagi siswa dan menjadi Uji Kompetensi Nasional untuk tingkat SMK. Mata Pelajaran Smart Relay/PLC termasuk dalam jurusan Praktek Teknik Instalasi Tenaga Listrik. Berdasarkan informasi dari ketua jurusan dan Wakil Kepala Sekolah, pembelajaran mata pelajaran Smart Relay/PLC belum optimal diajarkan, karena peralatan trainer yang kurang mendukung dan keterbatasan tenaga guru pengajar mata pelajaran Smart Relay. Peralatan yang masih belum lengkap dan kurang memadai menjadi salah satu faktor penghambat perkembangan siswa dalam pembelajaran.

Dunia usaha dan dunia industri (DUDI) menuntut SDM yang memiliki kualitas dan kompetensi yang sesuai dengan bidangnya. Dengan demikian, SMK wajib mempersiapkan peserta didik untuk memiliki kompetensi dan keahlihan yang dibutuhkan oleh dunia usaha maupun dunia industri. Salah satu faktor yang mempengaruhi keberhasilan peserta didik dalam menguasai suatu kompetensi adalah tenaga pendidik/guru. Guru wajib kreatif dan inovatif dalam menciptakan suasana belajar yang efektif dan tepat sasaran. Pembelajaran yang berorientasi pada siswa dapat meningkatkan keaktifan siswa sehingga kualitas pembelajaran meningkat. Saat ini tingkat inovasi guru dalam penyajian materi dengan media pembelajaran masih rendah, Seharusnya, guru dapat mempersiapkan pembelajaran dengan matang dan dapat mendorong siswa lebih aktif sehingga mendorong siswa lebih aktif tahunya. Hal tersebut membuat siswa terbiasa melakukan pembelajaran secara mandiri di sekolah maupun di luar sekolah. Oleh karena itu guru dituntut untuk mengembangkan kreativitas dan inovasi dalam menyajikan materi pembelajaran sehingga pembelajaran menjadi efektif dan menyenangkan.

Kompetensi merupakan hal yang harus dikuasai oleh seorang pengajar/guru dan peserta didik di SMK HKBP P. Siantar khususnya Jurusan Listrik (jarak lokasi dari Politeknik Negeri Medan adalah 123 km). Smart Relay merupakan materi yang diujikan pada kompetisi nasional. Merakit sistem Smart Relay merupakan kompetensi dasar yang diajarkan di SMK khususnya Jurusan Listrik, Elektronik dan mesin untuk program keahlian Otomasi Industri. Namun yang menjadi permasalahan di SMK HKBP Pematang Siantar adalah peralatan Smart Relay belum memadai dan belum didukung dengan peralatan trainer 
lainnya serta keterbatasan kompetensi guru pengajar khusus untuk smart relay/PLC. Gambar 1.2 memperlihatkan kondisi peralatan khususnya smart relay/PLC yang ada di laboratorium Jurusan Listrik SMK HKBP P. Siantar.

Dengan melihat permasalahan mitra tersebut maka kami sebagai tenaga pengajar di Polmed ingin membantu SMK HKBP P. Siantar dengan melaksanakan pelatihan Smart Relay/PLC dan melengkapi peralatan modul. Adapun metode yang akan dilaksanakan adalah melalui media pembelajaran Trainer Human Machine Interface (Trainer HMI), karena dinilai sesuai dengan kebutuhan pembelajaran pada mata pelajaran Instalasi Listrik.

\section{METODE}

Berdasarkan Solusi dan target luaran yang diharapkan, maka metode pelaksanaan kerjasama kemitraan ini dilakukan dengan cara seperti pada tabel 1.

Tabel 1. Metode Pelaksanaan

\begin{tabular}{|l|l|l|}
\hline No & \multicolumn{1}{|c|}{$\begin{array}{c}\text { Justifikasi Permasalahan } \\
\text { yang disepakati dalam kerja sama }\end{array}$} & Metode Pendekatan \\
\hline 1. & $\begin{array}{l}\text { Kurangnya pengetahuan tentang PLC bagi } \\
\text { guru SMK Listrik yang ada di Kota P. Siantar }\end{array}$ & $\begin{array}{l}\text { Pelatihan dan } \\
\text { implementasi }\end{array}$ \\
\hline 2. & $\begin{array}{l}\text { Masih kurangnya pengetahuan perkembangan } \\
\text { kontrol industri berbasis PLC }\end{array}$ & $\begin{array}{l}\text { Pelatihan dan } \\
\text { implementasi }\end{array}$ \\
\hline 3. & $\begin{array}{l}\text { Masih kurangnya pengetahuan tentang } \\
\text { pembuatan modul praktikum }\end{array}$ & $\begin{array}{l}\text { Pelatihan dan } \\
\text { implementasi }\end{array}$ \\
\hline 4. & $\begin{array}{l}\text { Masih kurangnya pengetahuan tentang } \\
\text { pengembangan modul praktikum }\end{array}$ & $\begin{array}{l}\text { Pelatihan dan } \\
\text { implementasi }\end{array}$ \\
\hline 5. & Masih terbatas guru pengajar PLC & $\begin{array}{l}\text { Pelatihan dan } \\
\text { implementasi }\end{array}$ \\
\hline
\end{tabular}

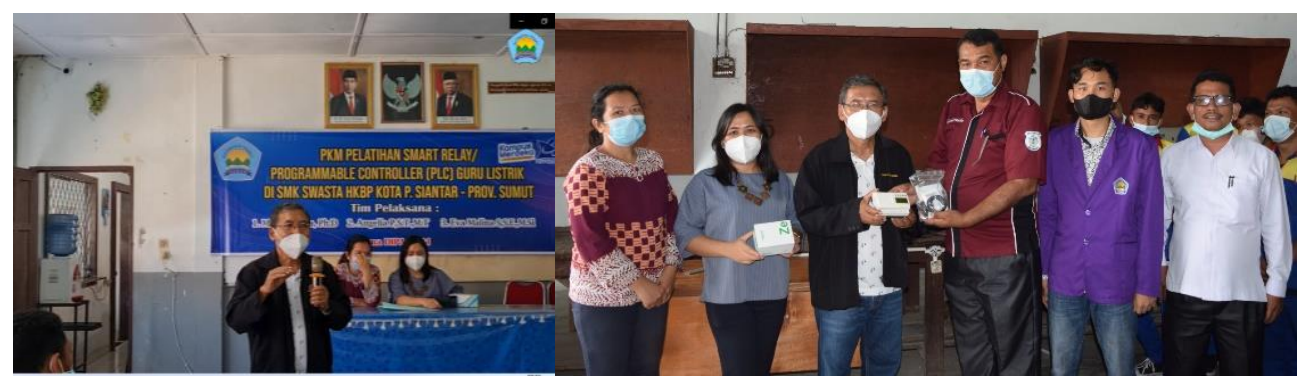

Gambar 1. Pendampingan Tim Pengabdian dan Penyerahan 1 set unit modul praktik berupa Smart Relay

Untuk dapat menjalankan kerjasama dengan sekolah mitra berdasarkan metode pelaksanaan maka ada beberapa prosedur kerja yaitu :

Tabel 2. Prosedur Kerja Metode Pelaksanaan

\begin{tabular}{|c|l|l|l|c|}
\hline No & $\begin{array}{c}\text { Prosedur } \\
\text { Kerja }\end{array}$ & Rencana Kegiatan & \multicolumn{1}{|c|}{$\begin{array}{c}\text { Partisipasi } \\
\text { Mitra }\end{array}$} & $\begin{array}{c}\text { Kurun Waktu } \\
\text { Realisasi Program }\end{array}$ \\
\hline 1. & $\begin{array}{l}\text { Pertemuan } \\
\text { awal }\end{array}$ & $\begin{array}{l}\text { Sosialisasi program } \\
\text { kerjasama }\end{array}$ & $\begin{array}{l}\text { Menghadiri } \\
\text { pertemuan awal }\end{array}$ & 100 menit \\
\hline
\end{tabular}




\begin{tabular}{|c|l|l|l|c|}
\hline 2. & Sosialisasi & $\begin{array}{l}\text { Menjelaskan secara } \\
\text { singkat tentang PLC }\end{array}$ & $\begin{array}{l}\text { Mengikuti } \\
\text { pelatihan }\end{array}$ & 100 menit \\
\hline 3. & Pelaporan & $\begin{array}{l}\text { Pelaporan seluruh } \\
\text { kegiatan kerjasama }\end{array}$ & $\begin{array}{l}\text { Membuat } \\
\text { laporan }\end{array}$ & Satu minggu \\
\hline
\end{tabular}

\section{HASIL DAN PEMBAHASAN}

Hasil dari kegiatan pengabdian kepada masyarakat terhadap peserta adalah tercapainya:

a. Mengenal dan memahami smart relay;

b. Mengetahui karakteristik smart relay;

c. Mengetahui cara kerja smart relay;

d. Dapat mengaplikasikan smart relay.

Selanjutnya, memberikan 1 set unit modul praktik berupa smart relay dengan komponen pendukung.

\section{KESIMPULAN}

Adapun simpulan dari kegiatan ini adalah:

1. Tujuan pelaksanaan pendampingan dan pelatihan tercapai.

2. Kegiatan PPM ini menambah 1 unit modul praktik penggunakan smart relay pada mata pelajaran Bengkel Instalasi Listrik.

\section{SARAN}

Adapun saran dari kegiatan ini adalah Pihak mitra menginginkan kegiatan ini dilakukan secara kontinu pada jurusan yang lain.

\section{UCAPAN TERIMA KASIH}

Para penulis dengan penuh rasa syukur menyampaikan penghargaan dan mengucapkan terima kasih atas dukungan finansial yang diberikan melalui dana DIPA Politeknik Negeri Medan tahun 2021 dengan nomor kontrak: B/652./PL5/PM.01.01/2021 tertanggal 25 Oktober 2021.

\section{DAFTAR PUSTAKA}

Abdillah, Margiono. (2018). Pengendali motor listrik dengan PLC (Zelio Smart Relay). Pontianak: YKT Publisher.

Azharman, Z., \& Susanti, E. (2020). Pembinaan Industri Kreatif Pada Jiwa Kewirausahaan Masyarakat. Puan Indonesia, 1(2), 65-70. https://doi.org/10.37296/about.v1i2.9

Facione, P. A., Sanchez, C, A., Facione, N, C, \& Gainen. (2010). The Disposition Toward Critical Thinking. Journal of General Education, 44(1), 1-25. 
Peraturan Presiden Republik Indonesia Nomor 8 Tahun 2012 tentang Kerangka Kualifikasi Nasional Indonesia.

Sajidan, Baedhowi, Triyanto, Salman A. T., Mohammad M. (2018). Peningkatan proses pembelajaran dan penilaian pembelajaran abad 21 dalam meningkatkan kualitas pembelajaran SMK. Jakarta Direktorat Pembinaan Sekolah Menengah Kejuruan Direktorat Jenderal Pendidikan Dasar dan Menengah Kementerian Pendidikan dan Kebudayaan.

Sugiyono. (2015). Metode penelitian pendidikan: pendekatan kuantitatif, kualitatif dan R\&D. Bandung: Alfabeta. Widyoko. (2014). Evaluasi program.

Undang-undang Republik Indonesia Nomor 20 Tahun 2003 tentang Sistem Pendidikan Nasional. Jakarta: Kementerian Pendidikan dan Kebudayaan. 
